\title{
DIVERSITAS ARTHROPODA PADA TANAMAN CABAI TRANSISI ORGANIK DENGAN APLIKASI BEART METHODS (Beaauveria bassiana, Refugia Area, Trichoderma spp) DAN BUDIDAYA KONVENSIONAL
}

\author{
Diversity Arthropoda on Chilli Organic Transition with Beart Methods (Beaauveria \\ bassiana, Refugia Area, Trichoderma spp) Application and Conventional Agriculture
}

\author{
Iqbal Erdiansyah*, Sekar Utami Putri, dan Eliyatiningsih \\ Jurusan Produksi Pertanian, Politeknik Negeri Jember \\ Jl Mastrip Kotak Pos 161-Jember 68101
}

Alamat korespondensi: iqbal@polije.ac.id

\begin{abstract}
ABSTRAK
Penelitian ini bertujuan untuk mengkaji investasi dan mengklasifikasi populasi Arthropoda pada lahan budidaya cabai merah (konvensional) dan transisi organik yang berperan sebagai musuh alami hama cabai merah. Penelitian ini dilaksanakan mulai bulan November 2018 sampai bulan Maret 2019, bertempat di lahan Dusun Gawok, Desa Dukuhdempok, Kecamatan Wuluhan, Kabupaten Jember. Penelitian ini dilakukan dengan menggunakan dua petak lahan yaitu teknik konvensional (menggunakan pestisida kimia) dan transisi organik (menggunakan Beauveria bassiana, Refugia Area, Trichoderma spp). Peubah pengamatan pada penelitian ini adalah investasi dan klasifikasi populasi serangga pada masing-masing petak lahan percobaan. Keanekaragaman arthropoda dianalisis menggunakan indeks diversitas Shannon Weiner dan indeks Dominansi. Hasil penelitian menunjukkan bahwa nilai Indeks Diversitas arthopoda berdasarkan Indeks Shanon-Wiener (H') pada petak lahan transisi organik lebih tinggi dibandingkan lahan petak konvensioanl yaitu masing-masong 1,623 $\pm 0,142$ dan $1,376 \pm 0,132$. Untuk tingkat spesies dominansi (C) tergolong kategori sedang di kedua petak percobaan. Nilai di petak lahan konvensional lebih tinggi dibandingkan dengan lahan petak transisi organik yaitu masing-masing $0,343 \pm 0,135$ dan $0,322 \pm 0,123$.
\end{abstract}

Kata kunci: arthropoda, budidaya konvensional dan transisi organik, cabai merah, indeks diversitas, indeks dominan.

\begin{abstract}
This research aimed to assess the investment and classify the Arthropod populations on red chili plantation (conventional) and organic transitions that act as natural enemies of red chili pests. This research was conducted from November 2018 to March 2019, located in Gawok Hamlet, Dukuhdempok Village, Wuluhan District, Jember. This research was conducted by using two kind of plots i.e. conventional technic (using full of synthetic pesticide) and organic transition technic (using Beauveria bassiana, Area Refugia, Trichoderma spp). The observation variables in this research were investment and classification of insect population in each treatment. Arthropod diversity was analyzed using the Shannon Weiner diversity index and Dominance index. The results showed that the value of Arthropoda Diversity Index base on Shanon-Wiener Index $\left(H^{\prime}\right)$ in organic transition technic was higher than conventional technic viz. $1.623 \pm 0.142$ and $1.376 \pm 0.132$, respectively. The level of species dominance (C) for both areas classified as moderate category. Conventional technic obtained the higher value than organic trantition technic viz. $0.343 \pm 0.135$ dan $0.322 \pm 0.123$, respectively.
\end{abstract}

Keywords: arthropod, conventional and organic transition technics, diversity index, dominance index, red chilli.

\section{PENDAHULUAN}

Cabai merah menjadi salah satu produk hortikultura yang selalu menjadi sorotan masyarakat. Harga cabai merah yang tinggi mampu menyumbang perekonomian Indonesia (Yanuarti dan
Mudya, 2016). Hal tersebut berkaitan dengan ketersediaan dan konsumsi cabai pada waktu tertentu. Berdasarkan data Kementerian Pertanian, total produksi cabai merah tahun 2016 sebesar 1,04 juta ton, sedangkan di tahun 2017 meningkat 1,21 
juta ton dan tahun 2019 sebesar 1,12 juta ton. Selanjutnya data konsumsi cabai merah Tahun 2016 sebesar 1,55 (kg/kapita), tahun 2017 sebesar 1,56 (kg/kapita) dan tahun 2019 sebesar 1,58 (kg/kapita) (Kementerian Perdagangan RI, 2019). Menurunnya jumlah produksi buah cabai pada beberapa tahun terakhir disebabkan oleh berbagai faktor, salah satunya adalah serangan hama dan penyakit tanaman. Tinggi rendahnya tingkat serangan hama dan penyakit pada tanaman cabai dipengaruhi oleh beberapa faktor, seperti teknik budidaya yang dilakukan dan kondisi ekosistem di lingkungan budidaya.

Cabai merah tergolong komoditas hortikultura yang memerlukan biaya perawatan tinggi, seperti pemupukan dan pengendalian hama penyakit tanaman (Eliyatiningsih et al., 2020). Petani selalu beranggapan bahwa pemberian pupuk kimia secara intensif akan menghasilkan produksi buah cabai yang tinggi. Namun, kegiatan ini akan berdampak pada meningkatnya serangan hama dan penyakit, karena akan memudahkan terjadinya infeksi hama dan patogen pada tanaman. Selain itu, kegiatan pengendalian hama dan penyakit yang dilakukan petani adalah dengan mengaplikasikan pestisida kimia secara intensif.

Petani beranggapan bahwa perlindungan tanaman dengan pestisida kimia akan mempertahankan jumlah produksi buah karena minimnya serangan hama dan penyakit. Namun kegiatan ini pun berdampak negatif dalam jangka panjang yaitu meninggalkan residu pada buah dan tanah, serta menyebabkan peningkatan resistensi hama (El-Wakeil et al., 2013). Residu pestisida kimia pada tanah mampu menyebabkan turunnya populasi mikroba tanah yang bermanfaat bagi tumbuhan. Populasi bakteri lebih tinggi daripada populasi fungi pada lahan yang teraplikasi insektisida (Sulistinah et al., 2011). Aplikasi pestisida kimia secara intensif akan membentuk sistem imun tersendiri pada hama sasaran, sehingga menyebabkan petani harus meningkatkan dosis pestisida apabila terdapat serangan hama yang serupa di lahan. Kondisi ini akan menyebabkan ketidakseimbangan pada ekosistem, karena pestisida kimia tidak hanya membasmi atau mengurangi populasi hama, tetapi juga parasitoid dan predator pada lahan. Hal ini yang menjadi sorotan untuk diperbaiki.

Pola budidaya ini yang perlu diubah secara perlahan untuk mendapatkan hasil yang maksimal dengan tetap menjaga ekosistem dan kesehatan produk. Pengendalian hama terpadu menjadi salah satu solusi untuk memperbaiki pola budidaya yang sudah mengakar di petani. Beberapa pengendalian yang bisa diaplikasikan antara lain pengendalian teknis dan biologi. Pengendalian secara teknis dilakukan dengan cara pemberian 
pupuk anorganik dan organik. Menurut Buysens et al. (2016), budidaya tanaman yang menambahkan mikroorganisme baik pada lahannya akan meningkatkan produksi tanaman. Trichoderma sp. memiliki kemampuan mendekomposisi bahan organik sehingga nutrisi tanaman tersedia dan meningkatkan ketahanan tanaman terhadap serangan penyakit. Trichoderma harzianum efektif sebagai agen biokontrol untuk mengendalikan penyakit busuk pangkal batang tanaman cabai yang disebabkan Fusarium oxysporum (Sutarman, 2017). Pengendalian biologi juga bisa dilakukan dengan menggunakan agensia hayati Beauveria bassiana dan menanam tanaman refugia pada areal lahan budidaya. Beauveria bassiana tergolong agen biokontrol yang memiliki kemampuan penetrasi tinggi sehingga mampu menginfeksi hama serangga penghisap seperti Aphid (Aphis sp) dan kutu kebul (Bemisia spp) (Soetopo dan Indrayani (2007)). Menurut penelitian Thalib et al. (2013), aplikasi Beauveria bassiana sebagai bioinsektisida mempengaruhi mortalitas nimfa Aphis gossypii dan semakin tinggi konsentrasi konidia, maka semakin pendek waktu mortalitas. Berdasarkan penelitian Sinulingga et al. (2019), tanaman refugia mampu meningkatkan jumlah parasitoid yang mampu mengendalikan wereng dengan ditunjukkan telur parasitoid yang lebih rendah menetas $(5,9 \%)$ pada refugia dibandingkan dengan lahan tanpa refugia $(14,54 \%)$.

Pengendalian hama dan penyakit tanaman secara terpadu penting untuk diterapkan dalam budidaya tanaman. Hal tersebut diharapkan dapat memberikan produksi maksimal dengan tetap menjaga ekosistem dan kesehatan produk. Penerapan PHT (Pengendalian Hama Terpadu) pada penelitian ini adalah dengan mengkombinasikan penggunaan agensia hayati Beauveria bassiana, pupuk hayati Trichoderma sp., dan refugia area pada budidaya cabai merah (Beart Methods). Metode ini diinisiasikan pada sentra penanaman cabai di Kabupaten Jember untuk menjaga keseimbangan ekosistem wilayah. Penelitian ini bertujuan untuk mengkaji investasi dan mengklasifikasi populasi Arthropoda pada lahan budidaya cabai merah konvensional dan transisi organik yang berperan sebagai musuh alami hama cabai merah.

\section{METODE PENELITIAN}

Penelitian ini dilakukan pada budidaya cabai varietas Imola F1 di Dusun Gawok, Desa Dukuhdempok, Kecamatan Wuluhan, Kabupaten Jember. Bahan lain yang dibutuhkan antara lain benih refugia (Zinnia sp dan Cosmos caudatus), pupuk kandang sapi, Beauveria bassiana (BV), Trichoderma sp (TC), insektisida kimia 
(Demolis $1 \mathrm{ml} / \mathrm{L}$, Pegasus 1,5-2 $\mathrm{ml} / \mathrm{L}$ dan Endure $1 \mathrm{ml} / \mathrm{L}$ ), mulsa hitam perak, pupuk SP36, pupuk NPK 16-16-16.

Budidaya cabai diawali dengan pengolahan lahan dan persiapan bibit. Bibit cabai dan refugia disemai pada tray dengan perbandingan media tanah dan pupuk kandang 1:1 selama satu bulan sebelum dipindah tanam ke lahan pengamatan. Lahan diolah menggunakan traktor dengan menambahkan pupuk kandang 20 $\mathrm{kg} /$ bedeng dan kapur dolomit $4 \mathrm{~kg} /$ bedeng serta SP36 16,7 g/tanaman. Ukuran bedeng yang digunakan $7 \times 1,2 \mathrm{~m}$; jarak antar bedeng $50 \mathrm{c} \mathrm{m}$, jarak lubang tanam 75x50 cm dan ditutup mulsa hitam perak (y, 2012). Lahan terdiri dari 2 lahan perlakuan antara lain: P0 (lahan kontrol/budidaya konvensional) merupakan lahan dengan penyemprotan pestisida kimia setiap tiga hari sekali. P1 (lahan transisi organik dengan aplikasi Beauveria bassiana+Trichoderma $\quad \mathrm{sp}+$ Refugia) merupakan lahan dengan aplikasi Beauveria bassiana $(10 \mathrm{~g} / \mathrm{L})$ setiap tiga hari sekali dengan dikombinasikan pengaplikasian pestisida kimia seminggu sekali dan diawal penanaman tiap lubang tanam diberikan Trichoderma sp 10 g/lubang serta ditanami Refugia dipinggiran bedengan. Refugia ditanam pada pinggiran lahan cabai dengan jarak 50 $\mathrm{cm}$ dari bedengan dan penanamannya secara berseling antara bunga kertas dan bunga kenikir dengan jarak $10 \mathrm{~cm}$.

Proses penanaman dilakukan dengan membasahi tanah di lahan pengamatan terlebih dahulu kemudian pindah tanam bibit cabai Imola. Refugia ditanam pada bagian pinggiran bedeng. Pengairan dilakukan setiap 2-3 hari setelah pindah tanam dan setiap 2 minggu sekali setelah tanaman berumur 4 MST (Minggu Setelah Tanam). Pemupukan lanjutan (NPK 16-1616) dilakukan setelah tanaman berumur 14 HST (Hari Setelah Tanam). Pemupukan lanjutan diaplikasikan dalam bentuk cair dengan konsentrasi $2 \mathrm{~g} / \mathrm{L}$ yaitu pada 14 dan 20 HST $100 \mathrm{ml} /$ tanaman; 29 dan 42 HST $200 \mathrm{ml} /$ tanaman, dan 56 HST 300 ml/tanaman (Sepwanti et al., 2016).

Pengambilan sampel serangga dan mencari kelimpahan serangga menggunakan Sweep Net dan Visual Control. Tujuan dari pengamatan pada penelitian ini adalah untuk mengkaji investasi dan mengklasifikasi populasi Arthropoda.

Peubah yang diamati meliputi:

1. Diversitas arthropoda

Pengamatan dilakukan menggunakan jaring serangga pada areal atas tanaman cabai konvensional dan transisi organik. Pengamatan ini dilakukan untuk mengklasifikasikan arthropoda yang ada di lahan perlakuan. Identifikasi berdasarkan Sanjaya dan Dibiantoro 
(2012). Pengidentifikasian ini berguna untuk mengetahui kelompok dan peranannya terhadap tanaman cabai.

2. Indeks diversitas Shannon-Weiner ( $\left.\mathrm{H}^{\prime}\right)$ Keragaman merupakan gabungan antara komponen varietas dan komponen kesamarataan sebagai satu indeks diversitas secara keseluruhan (Sanjaya dan Dibiantoro, 2012). Oleh karena itu, bila semakin besar jumlah individu setiap spesiesnya, maka nilai indeks diversitasnya akan semakin tinggi.

Nilai indeks diversitas ini dihitung berdasarkan indeks Shannon Wiener (Sanjaya dan Dibiantoro, 2012). Nilai indeks ini berkaitan dengan kondisi lingkungan dari komunitas tersebut. Indeks diversitas pada ekosistem yang secara fisik dikendalikan memiliki nilai yang rendah, sedangkan pada ekosistem alami memiliki nilai yang tinggi. Pengetahuan keanekaragaman jenis serangga pada kedua perlakuan yaitu tanaman cabai transisi organik dan konvensional merupakan ciri tingkatan komunitas berdasarkan organisasi biologinya. Keanekaragaman spesies dapat digunakan untuk menyatakan struktur komunitas. Keanekaragaman spesies juga dapat digunakan untuk mengukur stabilitas komunitas, yaitu kemampuan suatu komunitas untuk menjaga dirinya tetap stabil meskipun ada gangguan terhadap komponenkomponennya.

3. Indeks dominansi (C)

Dominansi spesies pada komunitas serangga yang diamati dihitung berdasarkan indeks dominansi Simpson menurut Sanjaya dan Dibiantoro (2012). Bila nilai indeks dominansi $<1$ maka spesies serangganya beranekaragam, sebaliknya bila nilai indeks dominansi $=1$, maka spesies serangganya tidak beranekaragam. Selain itu, menurut perhitungan Simpson, bila nilai indeks Simpson (C) berkisar antara 0,7 - 0,8 merupakan keadaan yang belum mengalami gangguan atau penceramaran, sedangkan bila $\mathrm{C}<0,7$ menunjukkan keadaan yang telah mengalami gangguan atau pencemaran. Indeks diversitas memberikan suatu cara terbaik untuk mengetahui dan menilai pencemaran. Spesies-spesies yang dominan pada kedua perlakuan yaitu transisi organik dan konvensional yang memiliki indeks nilai penting yang tinggi, sehingga spesies yang paling dominan tentu saja memiliki indeks nilai penting yang paling besar.

Data dianalisis menggunakan analisis non parametrik dengan SPSS versi 15.0 
Indeks diversitas Shannon-Wiener (H') menggunakan rumus:

$\mathrm{H}^{\prime}=-\sum_{i=1}^{s}\left[\left(\frac{n i}{N}\right) \ln \left(\frac{n i}{N}\right)\right]$

\section{Keterangan:}

$\mathrm{H}^{\prime}=$ indeks diversitas Shannon

$\mathrm{ni}=$ total individu spesies $\mathrm{i}$

$\mathrm{N}=$ total individu semua spesies.

Kriteria indeks diversitas Shannon-Wiener disajikan pada Tabel 1.

Indeks Dominansi menggunakan rumus:

$\mathrm{C}=\sum \mathrm{pi}^{\wedge} 2$

Keterangan:

$\mathrm{C}=$ Indeks Dominansi

pi = Jumlah individu dalam satu spesies dibagi Jumlah total individu spesies yang ditemukan.

\section{HASIL DAN PEMBAHASAN}

\section{Diversitas Arthropoda}

Refugia memiliki fungsi sebagai mikrohabitat musuh alami dan penarik hama tanaman. Tanaman berbunga inilah yang menjadi mikrohabitat pengendalian hama tanaman secara alami sehingga mendukung keseimbangan lingkungan (Erdiansyah dan Putri, 2018). Berdasarkan hasil penelitian (Tabel 2) yang telah dilakukan, terdapat beberapa serangga tertangkap berupa musuh alami baik herbivor, predator, parasitoid, polinator dan juga serangga yang menjadi hama pada tanaman budidaya cabai transisi organik dan konvensional itu sendiri maupun yang terdapat pada tanaman refugia.

Berdasarkan penelitian (Tabel 2) yang telah dilakukan, jumlah keseluruhan Arthopoda pada budidaya cabai transisi organik dan konvensional dari jumlah spesies rata-rata dari kedua perlakuan berbeda untuk herbivora yaitu pada budidaya cabai transisi organik terdapat 19 spesies antara lain: hama 6 spesies, predator 5 spesies, polinator 3 spesies, herbivora 3 spesies dan parasitoid 2 spesies, sedangkan untuk budidaya konvensional sendiri yaitu untuk hama 6 spesies, predator 5 spesies, polinator 3 spesies, herbivora 3 spesies dan parasitoid 0. Untuk kenaikan jumlah individu, spesies, famili pada budidaya cabai transisi organik adalah 601 spesies dan budidaya konvensional 299 spesies.

Jumlah arthopoda predator mengalami peningkatan yang sejalan dengan pertumbuhan tanaman cabai konversi organik dengan pengaplikasian pestisida nabati kombinasi yang menyebabkan di lahan budidaya konversi organik predator tinggi dan dapat menekan populasi dari hama. Keanekaragaman dapat dipengaruhi dengan agroekositem dan pertambahan umur tanaman cabai yang menyebabkan perubahan bentuk dan ukuran tanaman sehingga dapat ditempati oleh arthopoda hama dan menyediakann lebih banyak relung yang berikutnya yaitu 
Arthopoda predator (Erdiansyah et al.,

2018).

Tabel 1. Nilai dan deskripsi Indeks diversitas Shanon-Wiener (H')

\begin{tabular}{lll}
\hline \multicolumn{1}{c}{$\mathrm{H}^{\prime}<1.0$} & \multicolumn{1}{c}{$1.0<\mathrm{H}^{\prime}<3.22$} & \multicolumn{1}{c}{$\mathrm{H}^{\prime}>3.22$} \\
\hline - Diversitas rendah & - Diversitas sedang & - Diversitas tinggi \\
- Produktivitas rendah & - Produktivitas sedang & - Produktivitas tinggi \\
- Ekosistem tidak stabil & - Ekosistem seimbang & - Ekosistem stabil \\
\hline
\end{tabular}

Tabel 2. Keanekaragaman Fungsional Antropoda Pada Pertanaman Cabai Transisi Organik dan Konvensional

\begin{tabular}{|c|c|c|c|c|c|c|}
\hline \multirow[t]{2}{*}{ No } & \multirow[t]{2}{*}{ Nama Serangga } & \multirow[t]{2}{*}{ Ordo } & \multirow[t]{2}{*}{ Famili } & \multirow[t]{2}{*}{ Peran } & \multicolumn{2}{|c|}{$\begin{array}{l}\text { Jumlah } \\
\text { Individu }\end{array}$} \\
\hline & & & & & TOR & KNV \\
\hline 1. & Thrips tabaci & Tysanoptera & Thripidae & Hama & 45 & 55 \\
\hline 2. & Bemisia tabaci & Hemiptera & Aleyrodidae & Hama & 79 & 23 \\
\hline 3. & Aphis gossypii & Hemiptera & Aphididae & Hama & 45 & 22 \\
\hline 4. & Tetranycus sp & Aracnhida & Tetranychidae & Hama & 23 & 33 \\
\hline 5. & $\begin{array}{l}\text { Drosophila } \\
\text { melanogaster }\end{array}$ & Diptera & Drosophilidae & Hama & 55 & 32 \\
\hline 6. & Myzus percisae & Hemiptera & Aphididae & Hama & 53 & 23 \\
\hline 7. & $\begin{array}{l}\text { Pardosa } \\
\text { pseudoannulata }\end{array}$ & Araneae & Lycosidae & Predator & 41 & 10 \\
\hline 8. & Alopecosa sp & Araneae & Lycosidae & Predator & 32 & 13 \\
\hline 9. & Formicidae sp & Hymenoptera & Formicidae & Predator & 54 & 23 \\
\hline 10 & Alydidae $s p$ & Hemiptera & Alydidae & Herbivora & 22 & 9 \\
\hline 11. & Bactrocera spp & Diptera & Tephritidae & Herbivora & 13 & 5 \\
\hline 12. & Aulacophora indica & Coleoptera & Chrysomelidae & Herbivora & 11 & 2 \\
\hline 13. & Apis mellifera & Hymenoptera & Alididae & Polinator & 32 & 11 \\
\hline 14. & Capung/Anisoptera & Odonata & Anisoptera & Predator & 34 & 22 \\
\hline 15. & $\begin{array}{l}\text { Kupu kupu } \\
\text { Rhopalocera }\end{array}$ & Lepidoptera & Rhopalocera & Polinator & 28 & 11 \\
\hline 16. & Bombus terrestris & Hymenoptera & Apidae & Polinator & 13 & 2 \\
\hline 17. & $\begin{array}{l}\text { Epilachna } \\
\text { admirabilis }\end{array}$ & Coleoptera & Coccinellidae & Predator & 15 & 3 \\
\hline 18. & Rhyssa persuasoria & Hymenoptera & Ichneumonidae & Parasitoid & 3 & 0 \\
\hline 19. & Anagyrus greeni & Hymenoptera & Encyrtidae & Parasitoid & 3 & 0 \\
\hline Total & 19 Spesies & 8 Ordo & 13 Famili & & 601 & 299 \\
\hline
\end{tabular}

Keterangan: TOR $=$ Transisi Organik, KNV= Konvensional.

Keanekaragaman dan kelimpahan individu arthropoda pada teknik budidaya transisi organik lebih besar dibanding konvensional. Hal ini dapat disebabkan oleh aplikasi insektisida sintetik pada teknik budidaya konvensional telah menyebabkan perubahan pada agroekosistem. Agroekosistem yang terganggu akibat insektisida sintetik akan menyebabkan penurunan keanekaragaman arthropoda (Fitriani, 2016). 
Indeks Diversitas Shannon-Wiener (H') dan Indeks Dominansi

Berdasarkan analisis

menggunakan uji Paired sample T-test, teknik budidaya konvensional lebih rendah.

Hal ini dapat disebabkan oleh jumlah spesies konvensional lebih rendah dibanding konversi organik. Aplikasi insektisida sintetik pada budidaya konvensional dapat membunuh spesies bukan target insektisida. SID (Standart Indeks Dominansi) kedua teknik budidaya menunjukkan berbeda tidak nyata, hal ini disebabkan terdapat dominansi spesies pada masing-masing teknik budidaya (Agustinawati et al., 2016). Jenis arthropoda dapat dipengaruhi oleh pestisida. Pestisida secara langsung berpengaruh pada fauna tanah dan secara tidak langsung dampak aplikasi insektisida melalui rantai makanan (Sanjaya dan Dibiantoro, 2012).

Aktivitas predatorQ maupun parasitoid dapat mempengaruhi tingkat kerentanannya terhadap insektisida. Predator, parasitoid maupun polinator yang aktif bergerak, lebih rentan terhadap insektisida karena lebih sering kontak

Tabel 3. Indeks Diversitas Arthropoda pada Teknik Budidaya Cabai Konvensional dan Transisi Organik.

\begin{tabular}{lcc}
\hline \multirow{2}{*}{ Analisa Data } & \multicolumn{2}{c}{ Teknik Budidaya Cabai } \\
\cline { 2 - 3 } & Konvensional & Transisi organik \\
\cline { 2 - 3 } Shannon-Wiener (H') & $1,376 \pm 0,132 \mathrm{a}$ & $1,623 \pm 0,142 \mathrm{~b}$ \\
Dominansi (C) & $0,343 \pm 0,135 \mathrm{a}$ & $0,322 \pm 0,123 \mathrm{a}$ \\
\hline
\end{tabular}

Keterangan: angka yang diikuti huruf berbeda dalam baris yang sama menunjukkan berbeda nyata. dengan residu insektisida yang menempel pada permukaan tanaman. Insektisida juga dapat berpengaruh secara tidak langsung terhadap predator karena memangsa hama yang terkontaminasi insektisida. Herbivora mempunyai enzim yang mampu untuk mendetoksikasi senyawa beracun yang dimakannya, sedangkan predator tidak memiliki enzim tersebut. Ketersediaan pakan di lapang berupa polen, nektar yang terkontaminasi insektisida mempunyai pengaruh negatif terhadap populasi parasitoid, terutama dari ordo Hymenoptera (Kaleb et al., 2015).

Predator dan parasitoid berperan melawan hama utama cabai. Adanya refugia sebagai tanaman perangkap bagi hama sehingga hama tidak langsung menyerang tanaman utama (cabai). Trichoderma spp. berperan sebagai pendegradasi nutrisi pada lahan karena mengoptimalkan dekomposisi pupuk kandang pada lahan. Nutrisi yang tersedia secara optimal akan diserap pada lahan dan menyebabkan tanaman utama kuat dan tidak mudah terserang hama dan penyakit tanaman (Buysens et al., 2016). 

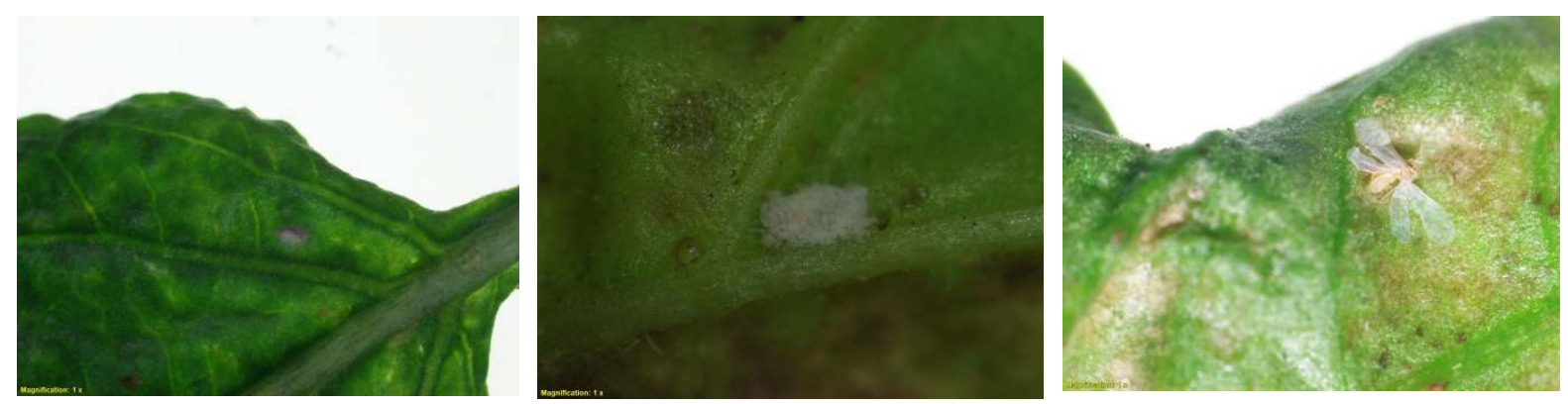

Gambar 1. Kutu Kebul yang terpenetrasi Beaauveria bassiana.

Peran Beauveria bassiana dalam lahan budidaya cabai transisi organik menunjukkan adanya pengendalian biologi dengan terjadi penetrasi pada kutu kebul (Gambar 1). Namun peran Beauveria bassiana disini masih belum optimal sehingga respon dalam mengendalikan hama pun belum maksimal. Menurut Soetopo dan Indrayani (2007), menjelaskan bahwa keefektifan Beauveria bassiana dalam menginfeksi serangga hama tergantung spesies atau strain cendawan dan kepekaan stadia serangga pada saat itu. Selain itu faktor lingkungan seperti tingkat kelembaban lingkungan, struktur tanah dan temperatur lingkungan mempengaruhi proses penetrasi Beauveria bassiana

\section{KESIMPULAN}

1. Lahan budidaya cabai transisi organik dan konvensional telah terinvestasi 19 spesies, 8 Ordo dan 13 Famili serangga dengan komposisi sama untuk hama, predator, pollinator, dan herbivora.

2. Indeks dominansi spesies (C) pada teknik budidaya transisi organik lebih rendah dibanding lahan konvensional. Sedangkan Indeks Shannon-Wiener
(H') tergolong kategori sedang, teknik budidaya transisi organik lebih rendah jumlah individu dibanding konvensional.

\section{DAFTAR PUSTAKA}

Agustinawati, M. H. Toana, A. Wahid. 2016. Keanekaragaman arthropoda permukaan tanah pada tanaman cabai (Capsicum Annum L.) dengan sistem pertanaman yang berbeda di Kabupaten Sigi. e-J. Agrotekbis, 4 (1): 8-15.

Buysens, C., V. César, F. Ferrais, H.D. Boulois, S. Declerck. 2016. Inoculation of Medicago sativa cover crop with Rhizophagus irregularis and Trichoderma harzianum increases the yield of subsequentlygrown potato under low nutrient conditions. Applied Soil Ecology, 105(9): 137-143.

El-Wakeil, N., N. Gaafar, A. Sallam, C. Volkmar. 2013. Side effects of insecticides on natural enemies and possibility of their integration in plant protection strategies. In book: Insecticides - development of safer and more effective technologies.

Eliyatiningsih, I. Erdiansyah, S.U Putri. 2020. The implementation of integrated pest management technology in red chili farming (case study of Dukuh Dempok Village, Wuluhan District, Jember Regency). IOP Conference Series: Earth and 
Environmental Science, Second International Conference on Food and Agriculture. Bali, 2-3 November 2019.

Erdiansyah, I., D.R.K. Ningrum, F.N.U Damanhuri. 2018. Pemanfaatan tanaman bunga marigold dan kacang hias terhadap populasi arthropoda pada tanaman padi sawah. Agriprima, Journal of Applied Agricultural Sciences, 2(2): 117-125.

Erdiansyah, I dan S.U. Putri. 2018. Implementasi tanaman refugia dan peran serangga pada tanaman padi sawah (Oryza Sativa L.) di Kabupaten Jember. Jurnal Agrin, 22 (2): 123131.

Fitriani. 2016. Keanekaragaman arthropoda pada ekosistem tanaman padi dengan aplikasi pestisida. Agrovital, 1(1): 68.

Kaleb, R., F. Pasaru, N. Khasanah. 2015. Keanekaragaman serangga musuh alami pada pertanaman bawang merah (Allium Ascalonicum L) yang diaplikasi dengan bioinsektisida Beauveria bassiana (Bals.-Criv.) Vuill. J. Agroland, 22(2): 114-122.

Kementerian Perdagangan RI. 2019. Analisis perkembangan harga bahan pangan pokok di pasar domestik dan internasional. Badan Pengkajian dan Pengembangan Perdagangan, Kementerian Perdagangan, RI.

Sepwanti, C., M. Rahmawati dan E. Kesumawati. 2016. Pengaruh varietas dan dosis kompos yang diperkaya Tricoderma harzianum terhadap pertumbuhan dan hasil tanaman cabai merah (Capsicum annum L.). Jurnal Kawista Agroteknologi, 1(1): 68-74.

Sinulingga, N.G.H, Y.A. Trisyono, E. Martono, B. Hadi. 2019. Benefits of flowering plant as refuge to improve the ecosystems services by egg parasitoids of the rice brown planthopper. Jurnal Perlindungan Tanaman Indonesia, 23(1): 68-74.

Soetopo, D. dan I. Indrayani. 2007. Status teknologi dan prospek Beauveria Bassiana untuk pengendalian serangga hama tanaman perkebunan yang ramah lingkungan. Perspektif, 6(1): 29-46.

Sulistinah, N., S. Antonius, M. Rahmansyah. 2011. Pengaruh residu pestisida terhadap pola populasi bakteri dan fungsi tanah di rumah kaca. Jurnal Teknologi Lingkungan, 12(1): 43-53.

Sutarman. 2017. Potensi Trichoderma harzianum sebagai pengendalian Fusariun oxysporum penyebab busuk pangkal batang tanaman cabai merah (Capsicum annum L.). Agritech, 19(2): 144-155.

Thalib, R., Firmansyah, T. Adam, A. Mazid, S. Herlinda. 2013. Bioaktivitas formulasi padat Beauveria bassiana (Balsamo) Vuill. dari tanah rawa terhadap Nimfa Aphis gossypii (Glover) (Homoptera: Aphididae). Prosiding Seminar Nasional Lahan Suboptimal Intensifikasi Pengelolaan Lahan Suboptimal dalam Rangka mendukung Kemandirian Pangan Nasional. Palembang, 20-21 September 2013

Yanuarti, A.R. dan M.D. Afsari. 2016. Profil komoditas barang kebutuhan pokok dan barang penting komoditas cabai. Kementerian Perdagangan, RI.

Sanjaya, Y. dan A.L.H. Dibiyantoro. 2012. Keragaman serangga pada tanaman cabai (Capsicum annuum) yang diberi pestisida sintetis versus biopestisida racun laba-laba (Nephila Sp.). J. HPT Tropika, 12(2): 192-199. 